UDC 629.3.025.2(045)

DOI:10.18372/1990-5548.64.14860

${ }^{1}$ O. A. Sushchenko, ${ }^{2}$ V. O. Golitsyn,

${ }^{3}$ A. A. Salyuk,

${ }^{4}$ S. H. Yehorov

\title{
AUTOMATED DESIGN OF AUTONOMOUS VECTOR MEASURING INSTRUMENTS
}

Faculty of Air Navigation, Electronics and Telecommunications, National Aviation University, Kyiv, Ukraine

E-mails: 'sushoa@ukr.net, ORCID 0000-0002-8837-1521, ${ }^{2}$ vova.gol@uk.net, ${ }^{3}$ sashalok511@gmail.com, 4avionika2006@ukr.net

\begin{abstract}
The process of designing autonomous vector measuring instrument is considered. The characteristic of autonomous vector measuring instruments applied in unmanned aviation is given. The concept of the smart measuring instrument concerning to the researched device is explained. The structure of information support for designing redundant nonorthogonal measuring instrument is given. The block-scheme of the process of designing redundant nonorthogonal configurations is represented. The process of choice of the optimal configuration of autonomous vector measuring instruments based on redundant nonorthogonal measuring bases is represented. The computer-aided designed procedures for optimal configuration choice are described. The basic algorithms necessary for functioning of the smart vector measuring instruments are listed. The example of the analysis of nonorthogonal configurations is represented. The obtained results are applicable in measuring systems of unmanned aviation. They also can be useful for other aerospace applications.
\end{abstract}

Index Terms - Autonomous vector measuring instruments; computer-aided design; nonorthogonal configuration; redundancy; smart measuring instrument.

\section{INTRODUCTION}

Successful solving problems dealt with control of moving vehicles including aircraft and spacecraft is largely determined by the level of developing measuring instruments and computer technologies. Further development of unmanned aviation is impossible without improvement these areas.

One of basic problems in area of application and developing airborne measuring instruments and measuring and computing systems is continuous improving accuracy, speed of operation, reliability, durability, and profitability of their operation.

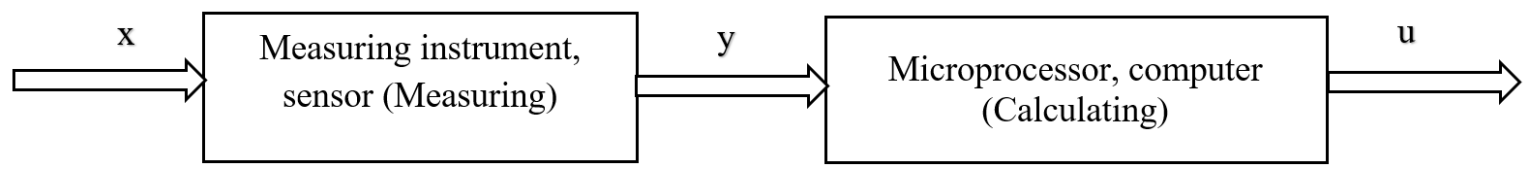

Fig. 1. The scheme of the smart measuring instrument

Development of any smart measuring instrument includes information, mathematical, algorithmic, program, technical, and methodical supports. The article deals with aspects developing these supports regarding to measuring instruments of aerospace applications (unmanned aerial vehicles and artificial earth satellite). The above mentioned controlled objects use such measuring instruments as gyroscopes, accelerometers, and magnetometers.

\section{PROBLEM STATEMENT}

The modern trend of measuring technique is integration of measuring instruments assigned for measuring primary information and processing the obtained information. Modern devices and sensors are developed and used in practical situations under information computer technologies [1]. By these technologies sensors, devices and also information and navigation systems are considered as information and measuring systems [2]. Such an approach corresponds to creating the so-called smart measuring instruments in accordance with a scheme represented in Fig. 1
These measuring instruments have two basic properties. Firstly, these measuring instruments are autonomous. Secondly, they are able to measure vectors and their components.

The main goal of the article is development of smart measuring instruments based on such sensors as gyroscopes accelerometer, and magnetometers.

Solving this problem requires researching two problems. On the one hand, it is necessary to 
improve the measuring part of the smart instrument. On another hand, it is measuring desirable to improve calculating part of the smart measuring instrument including algorithms able to increase accuracy and reliability of the measuring instruments as a whole.

\section{Automated Design of SMART MEASURING INSTRUMENT BASED ON NONORTHOGONAL}

It is known [2] that improvement accuracy and reliability of measuring process can be achieved by means of redundancy. There are such types of redundancies as structural, functional, code, and algorithmic.

The structural redundancy can be implemented in two ways such as reservation and integration. In its turn, the reservation can be implemented based on sensors or measuring bases [2], [3]. Finally, redundant measuring bases can be orthogonal and nonorthogonal. It should be noted that the nonorthogonal basis can be formed by measuring instruments with noncollinear and noncoplanar sensitivity axes.

Designing measuring instruments with redundant nonorthogonal measuring bases deals with a great number of transformations and calculations. Its successful implementation is impossible without using computer-aided design procedures with appropriate information and algorithmic supports [4].

The structure of the information support concerning to improving measuring part of the smart measuring instrument assigned for autonomous vector measurements is represented in Fig 2. The most important blocks of this structure are requirements to the measuring instrument depending on the application area, information about sensor characteristics, and information about possible structures of redundant nonorthogonal configurations of autonomous vector measuring instruments.

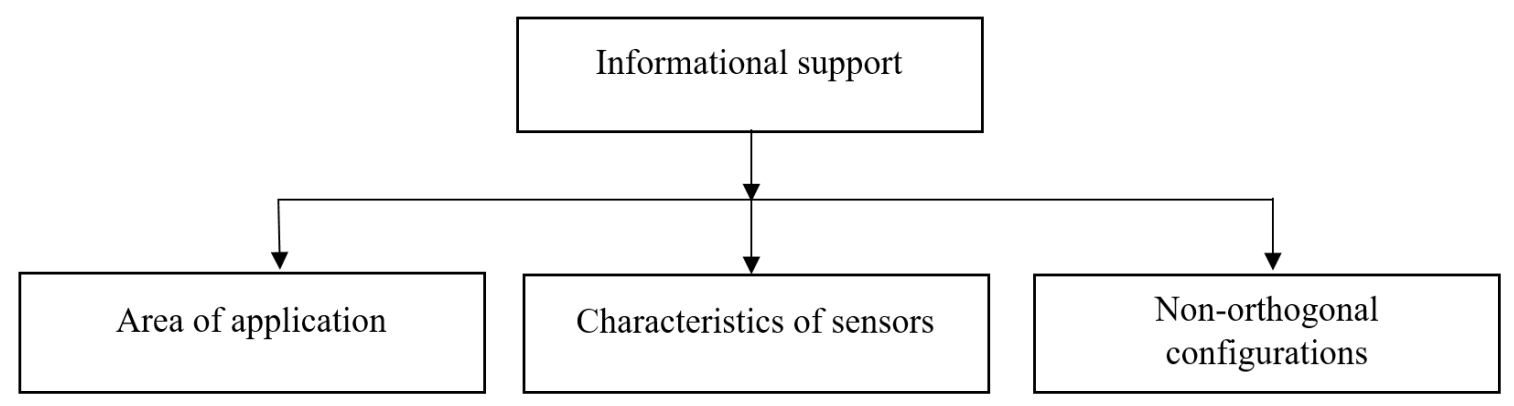

Fig. 2. Structure of information support for improving the measuring part of the smart sensor

The choice of a concrete computer-aided design procedure depends essentially on a type of the application: space or aerial. In its turn, a type of the UAV is important too. Control systems of heavy UAVs are close to ones of aircraft by the complexity of control laws and accuracy performances of sensors. Therefore for space application and heavy UAVs, it is convenient to use single sensors (gyroscopes, accelerometers, and magnetometer) with improved characteristics, but, of course, the more expensive. Moreover, in the first case, it is desirable to use single-axis sensors. In the second case, we can use inertial measuring units designed as a single module. In other words, three-axial gyroscopes, accelerometers, and magnetometers can be used for this application. It is possible to say that the choice of a type of the sensor determines its structure in some way (a number of axes of a measuring instrument is taken into consideration).

Next stage lies in the choice of a measuring instrument from the point of view of physical principle of operation and basic characteristics (first of all, accuracy and reliability).
It is convenient to mention here basic types of autonomous vector measuring instruments [3].

1) Gyroscopes such as laser, fiber-optic, rotor, float, vibratory, electrostatic, solid state wave, and dynamically tuned gyroscopes.

2) Accelerometers such as mass spring, pendulum, quartz, piezoelectric, magnet-elastic, string, float, MEMS.

3) Magnetometers such as flux-gate, ferroresonant, galvanic magnet, magnetic resistive, auto generator, quantum.

Basic parameters necessary for sensor choice are measuring range, resolution, accuracy (root mean square).

A basic feature of the redundant nonorthogonal measuring instruments is the necessity to choose an optimal configuration of separate sensors. Based on [2], it is possible to make conclusion about expediency of using such a geometrical figure as a cone for nonorthogonal configurations based on single axis sensors and polyhedrons for nonorthogonal configurations based on triaxial measuring units (see in Fig. 3a and b). 


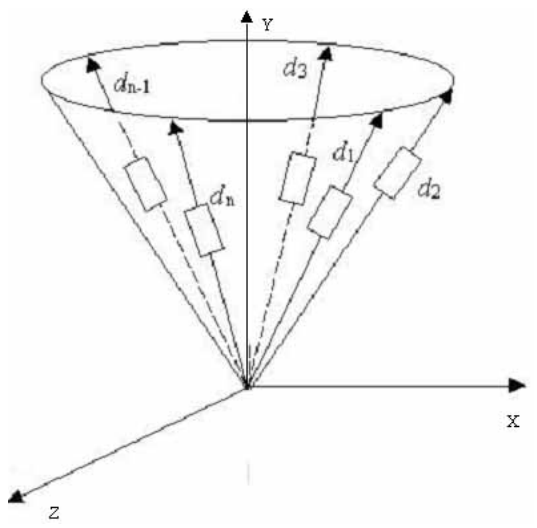

(a)

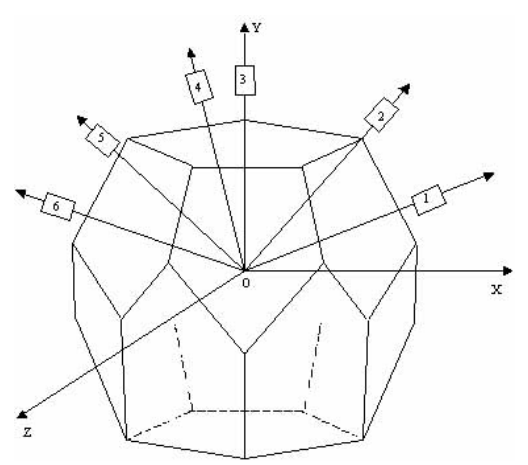

(b)

Fig. 3. Examples of nonorthogonal configurations: (a) is the based on a cone; (b) is the based on a polyhedrone
Characteristics of the most widespread nonorthogonal configurations are represented in Tables I and II.

TABle I. NONORTHOgONAl CONFIGURATIONS BASEd ON Such a GeOMETRICAL Figure AS A CONE

\begin{tabular}{|l|l|}
\hline No & Description of a configuration \\
\hline 1 & 4 sensors along a cone's generators \\
\hline 2 & $\begin{array}{l}\text { 3 sensors along a cone's generators and 1 } \\
\text { along the axis of symmetry }\end{array}$ \\
\hline 3 & 5 sensors along a cone's generators \\
\hline 4 & $\begin{array}{l}4 \text { sensors along a cone's generators and 1 } \\
\text { along the axis of symmetry }\end{array}$ \\
\hline 5 & 6 sensors along a cone's generators \\
\hline 6 & $\begin{array}{l}5 \text { sensors along a cone's generators and 1 } \\
\text { along the axis of symmetry }\end{array}$ \\
\hline
\end{tabular}

It should be noted that the information support in the part of nonorthogonal configurations must especially include matrices of directional cosines, which correspond to a definite configuration.

As example, consider a matrix of directional cosines for the nonorthogonal configuration consisting of 6 sensors located along a cone's generators. This matrix is represented as a Table III [5].

The matrix represented in Table III defines correspondence between axes of navigation reference frame $x y z$ and measuring reference frame $d_{1}, d_{2}, d_{3}, d_{4}, d_{5}, d_{6}[6]$.

Table II. Nonorthogonal CONFIgurations Based on PolyHedrons

\begin{tabular}{|c|c|c|c|c|c|}
\hline No & Polyhedron & Number of vertexes & Number of ribs & $\begin{array}{c}\text { Number of } \\
\text { facets }\end{array}$ & $\begin{array}{c}\text { Maximal number } \\
\text { of sensors }\end{array}$ \\
\hline 1 & Hexahedron & 8 & 6 & 4 & 4 \\
\hline 2 & Tetrahedron & 4 & 6 & 4 & 4 \\
\hline 3 & Octahedron & 6 & 12 & 8 & 4 \\
\hline 12 & Dodecahedron & 20 & 30 & 12 & 6 \\
\hline 5 & Icosahedron & 12 & 30 & 20 & 10 \\
\hline
\end{tabular}

TABLE III. MATRIX OF DiRECTIONAL COSINES FOR SENSORS LOCATED ON A CONE's GENERATORS

\begin{tabular}{|l|c|c|c|}
\hline & $x$ & $y$ & $z$ \\
\hline$d_{1}$ & 0 & $\cos \vartheta$ & $\sin \vartheta$ \\
\hline$d_{2}$ & $\sin \pi / 3 \sin \vartheta$ & $\cos \vartheta$ & $\cos \pi / 3 \sin \vartheta$ \\
\hline$d_{3}$ & $\sin \pi / 3 \sin \vartheta$ & $\cos \vartheta$ & $-\cos \pi / 3 \sin \vartheta$ \\
\hline$d_{4}$ & 0 & $\cos \vartheta$ & $-\sin \vartheta$ \\
\hline$d_{5}$ & $-\sin \pi / 3 \sin \vartheta$ & $\cos \vartheta$ & $-\cos \pi / 3 \sin \vartheta$ \\
\hline$d_{6}$ & $-\sin \pi / 3 \sin \vartheta$ & $\cos \vartheta$ & $\cos \pi / 3 \sin \vartheta$ \\
\hline
\end{tabular}

Taking into consideration [4], [7], [8] the blockscheme of the process of designing the smart measuring instruments based on autonomous vector sensors and nonorthogonal redundant configurations is represented in Fig. 4.

The feature of this algorithm is that it includes designing of both measuring and calculating parts. Algorithms and correspondingly software are integral parts of a measuring instrument on the whole.

This block-scheme includes also the choice of the optimal redundant nonorthogonal configuration of autonomous vector sensors (gyroscopes, accelerometers, and magnetometers). 


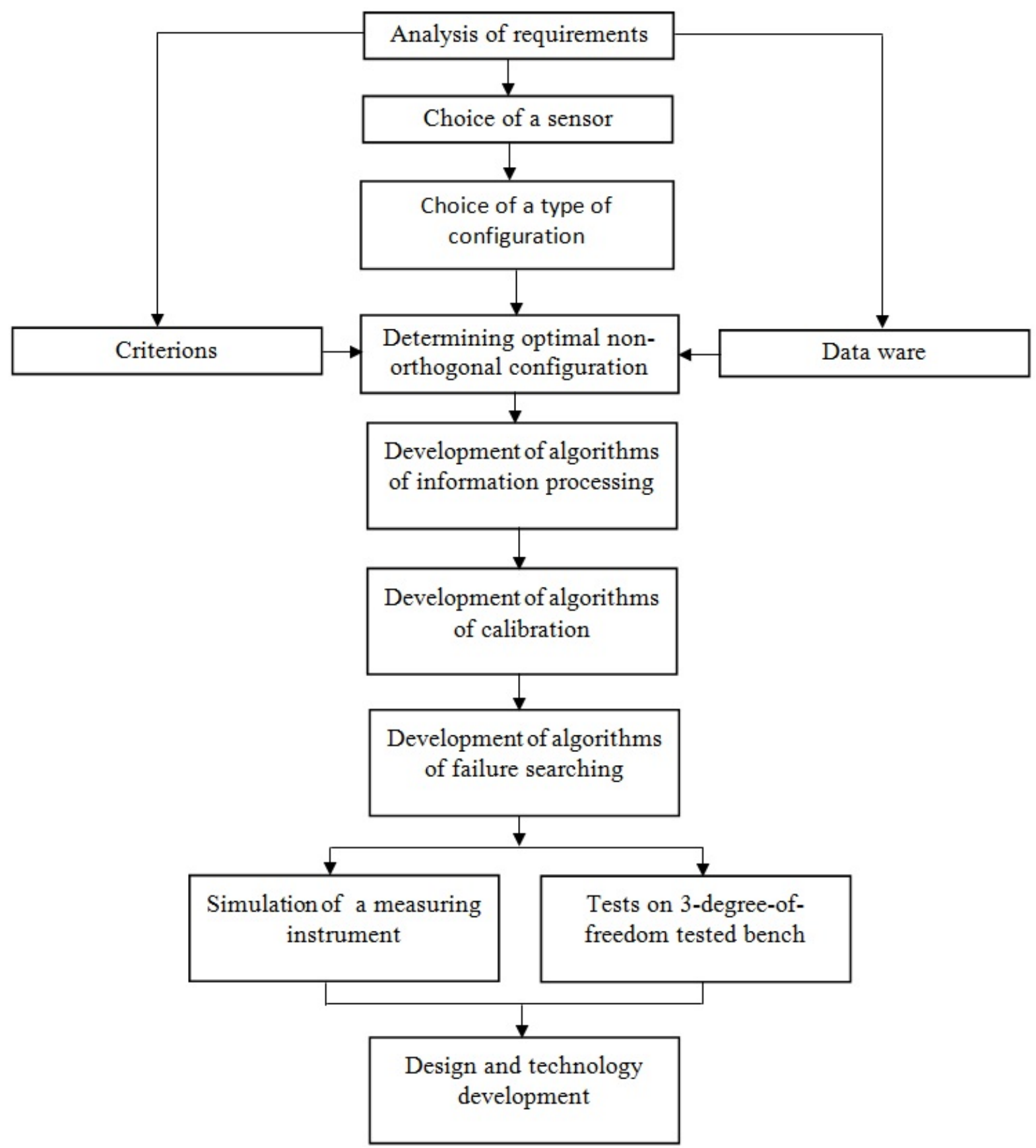

Fig. 4. The block-scheme of the process of designing the smart measuring instrument

The block of the choice of the optimal nonorthogonal configuration can be solved using automated means only. The basic design procedures of this process are represented in Fig. 5. Algorithms of information processing can be based on many approaches including averaging, median, and weighting averaging. Various filters can be applied too. It worth be mentioning Kalman filter, complementary filter. The great meaning has the integration of information of sensors. It is convenient to use new approaches, first of all algorithm of processing information based on neural networks. Calibration algorithms are based on weighting averaging. Learning by means of neural networks sufficiently well combines with neural networks. Algorithms of searching failures can be implemented in different ways. Firstly, it is possible to determine two maximal errors and exclude appropriate sensors from the process of information forming. Secondly, it is possible to carry out calculation of new errors after identification of failed sensor. 


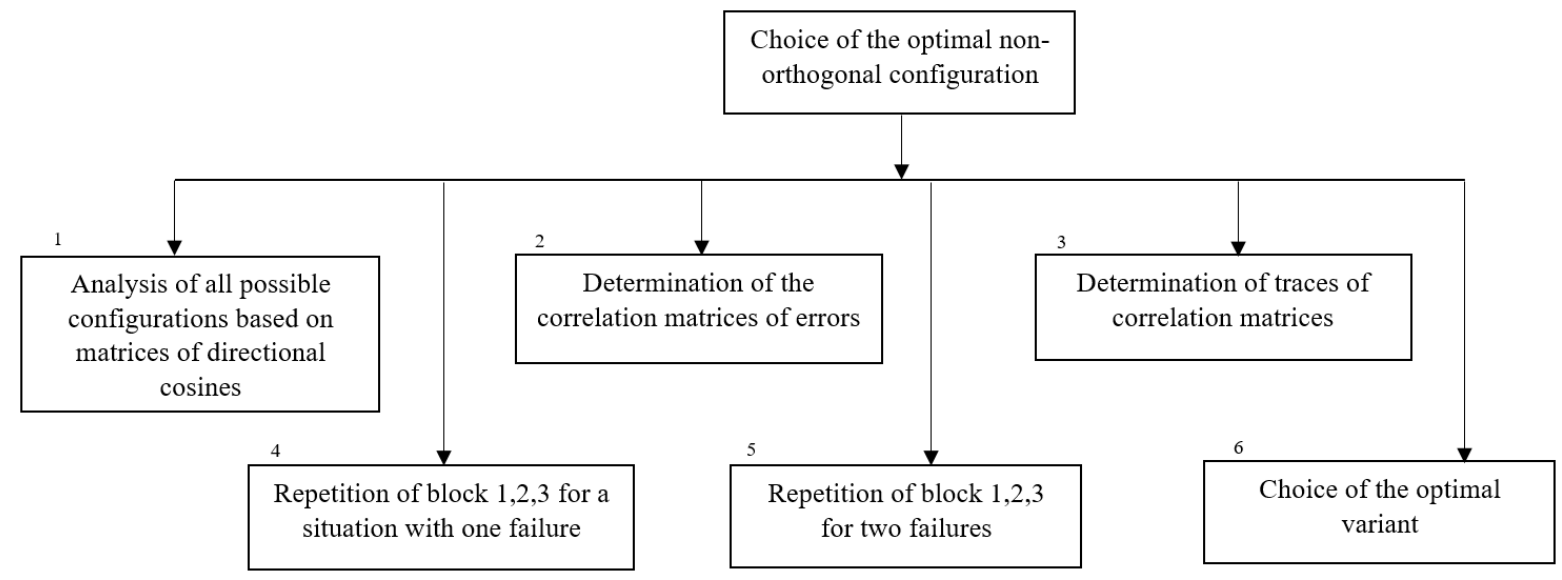

Fig. 5. Computer-aided design procedures on the choice of optimal nonorthogonal configuration of autonomous vector measuring instruments

Results of analysis of possible nonorthogonal configurations are represented in Table IV [9].

TABLE IV. COMPARATIVE ANALYSIS OF DiFFERENT NONORTHOGONAL CONFIGURATIONS

\begin{tabular}{|l|c|c|c|}
\hline Configuration & $\begin{array}{c}\text { All } \\
\text { sensors }\end{array}$ & $\begin{array}{c}\text { Failure of } \\
\text { 1 sensor }\end{array}$ & $\begin{array}{c}\text { Failure of } \\
\text { 2 sensors }\end{array}$ \\
\hline $\begin{array}{l}5 \text { sensors along } \\
\text { cone generators }\end{array}$ & 2.21 & 3.20 & 3.92 \\
\hline $\begin{array}{l}4 \text { sensors along } \\
\text { cone generators } \\
\text { and 1 along the } \\
\text { axis of } \\
\text { symmetry }\end{array}$ & 1.93 & 3.15 & 5.00 \\
\hline $\begin{array}{l}6 \text { sensors along } \\
\text { cone generators }\end{array}$ & 1.79 & 2.13 & 4.50 \\
\hline $\begin{array}{l}5 \text { sensors along } \\
\text { cone generators } \\
\text { an 1 along the } \\
\text { axis of } \\
\text { symmetry }\end{array}$ & 1.70 & 2.18 & 3.35 \\
\hline $\begin{array}{l}6 \text { sensors along } \\
\text { dodecahedron } \\
\text { facets }\end{array}$ & 1.50 & 2.00 & 3.00 \\
\hline
\end{tabular}

The analysis has been carried out on traces of correlation matrices of errors.

\section{CONCLUSIONS}

The basic principles of the computer-aided designing autonomous vector measuring instruments are represented. The structural scheme of the process of designing the intellectual measuring instrument concerning to the researched device is represented. The most important subsystems of the choice of optimal redundant nonorthogonal configuration are represented. The proposed approach allows decreasing the design time and improving quality of design process due to automation of complex and labour-intensiveness calculations and transformations.

\section{REFERENCES}

[1] G. Meijer, K. Makinwa, and M. Pertijs, Smart Sensor Systems. Emerging Technologies and Applications, Hoboken: Wiley, 2014, 296 p. https://doi.org/10.1002/9781118701508

[2] A. D. Epifanov. Reliability of Control Systems, Moscow: Mashinostroenie, 1975, 180 p. (in Russian).

[3] A. A. Ignatyev and G. M. Proskuryakov, Heterometry: algorithms, techniques of calibrating magnetometer blocks. Saratov: SU Publ., 2014, 152 p. (in Russian)

[4] R. I. Solnitsev, Automation of Automatic Control Systems. Moscow: Vishca shkola, 1991, 335 p.

[5] O. A. Sushchenko Y. N. Bezkorovainyi, and N. D. Novytska, "Theoretical and experimental assessments of accuracy of nonorthogonal MEMS sensor arrays," Eastern European Journal, 2018, vol. 3, no. 9 (93), pp. $\quad 40-49$. https://doi.org/10.15587/17294061.2018.131945

[6] O.A. Sushchenko, Y.N. Bezkorovainyi, and N.D. Novytska, "Dynamic analysis of nonorthogonal redundant inertial measuring units based on MEMSsensors," in Proceedings of 2018 IEEE 38th International Conference on Electronics and Nanotechnology, ELNANO, April 24-26, 2018, Kyiv, Ukraine, pp. 464-469. https://doi.org/10.1109/ELNANO.2018.8477553

[7] M. Jafari and J. Roshanian, "Optimal redundant sensor configuration for accuracy and reliability increasing in space inertial navigation systems," The journal of navigation, 2013, vol. 66, pp. 199-208. https://doi.org/10.1017/S0373463312000434

[8] S. A. Zotov, M. C. Rivers, A. A. Trusov, A. M. Shkel, "Folded MEMS pyramid inertial measurement unit," IEEE Sensors Journal, 2011, vol. 11, no. 11, pp. 2780-2789.

https://doi.org/10.1109/JSEN.2011.2160719 
[9] O. A. Sushchenko, Y. M. Bezkorovainyi, and V. O. Golytsin, "Processing of redundant information in airborne electronic systems by means of neural networks," in Proceedings of IEEE 39th International
Conference (ELNANO-2019), April 16-18, 2019, Kyiv, Ukraine, pp. 652-655

https://doi.org/10.1109/ELNANO.2019.8783394

Received April 29, 2020

Sushchenko Olha. orcid.org/0000-0002-8837-1521. Doctor of Engineering. Professor.

Faculty of Air Navigation, Electronics and Telecommunications, National Aviation University, Kyiv, Ukraine.

Education: Kyiv Polytechnic Institute, Kyiv, Ukraine, (1980).

Research area: systems for stabilization of information-measuring devices operated at vehicles of the wide class.

Publications: 250.

E-mail: sushoa@ukr.net

Golitsyn Volodymyr. Post-graduate student.

Faculty of Air Navigation, Electronics and Telecommunications, National Aviation University, Kyiv, Ukraine.

Education: National Aviation University, (2018).

Research area: information-measuring instruments.

Publications: 5.

E-mail: vova.gol@ukr.net

Salyuk Alexander Alekseevich. Bachelor.

Faculty of Air Navigation, Electronics and Telecommunications, National Aviation University, Kyiv, Ukraine.

Education: National Aviation University, Kyiv (2019).

Research area : information-measuring devices.

Publications: 1.

E-mail:sashalok511@gmail.com

Yehorov Serhey. Senior teacher.

Faculty of Air Navigation, Electronics and Telecommunications, National Aviation University, Kyiv, Ukraine.

Education: Kharkiv Aviation Institute, (1979).

Research area: control and avionics systems.

Publications: 30.

E-mail: avionika2006@ukr.net

О. А. Сущенко, В. О. Голіцин, О. О. Салюк, С. Г. Сгоров. Автоматизоване проектування автономних векторних вимірювачів

Розглянуто процес проектування автономного векторного вимірювача. Надано характеристику автономних векторних вимірювальних приладів, що застосовуються в безпілотній авіації. Пояснено концепцію інтелектуальних вимірювачів, до яких відноситься досліджуваний пристрій. Наведено структуру інформаційного забезпечення проектування надмірного неортогонального вимірювального приладу. Показано блок-схему процесу проектування надмірних неортогональних конфігурацій. Представлено процес вибору оптимальної конфігурації автономних векторних вимірювальних приладів на основі надлишкових неортогональних вимірювальних базисів. Описано автоматизовані процедури вибору оптимальної конфігурації. Перераховано основні алгоритми, необхідні для функціонування інтелектуальних векторних вимірювальних приладів. Наведено приклад аналізу неортогональних конфігурацій. Отримані результати можуть бути застосовані в вимірювальних системах безпілотної авіації. Також ці результати можуть бути корисними для інших аерокосмічних застосувань.

Ключові слова: автономні векторні вимірювальні прилади; системи автоматизованого проектування; неортогональна конфігурація; резервування; інтелектуальний вимірювальний прилад.

Сущенко Ольга Андріївна. orcid.org/0000-0002-8837-1521 Доктор технічних наук. Професор.

Факультет аеронавігації, електроніки та телекомунікацій, Національний авіаційний університет, Київ, Україна. Освіта: Київський політехнічний інститут, Київ, Україна, (1980).

Напрям наукової діяльності: системи стабілізації інформаційно-вимірювальних пристроїв, експлуатованих на рухомих об’ єктах широкого класу.

Кількість публікацій: 250.

E-mail: sushoa@ukr.net

Голіцин Володимир Олександрович. Аспірант.

Факультет аеронавігації, електроніки та телекомунікацій, Національний авіаційний університет, Київ, Україна. Освіта: Національний авіаційний університет, (2018).

Напрям наукової діяльності: інформаційно-вимірювальні пристрої.

Кількість публікацій: 5.

E-mail: vova.gol@ukr.net 
Салюк Олександр Олексійович. Бакалавр.

Факультет аеронавігації, електроніки та телекомунікацій, Національний авіаційний університет, Київ, Україна. Освіта: Національний авіаційний університет, Київ, (2019).

Напрям наукової діяльності: інформаційно-вимірювальні прилади.

Кількість публікацій :1.

E-mail: sashalok511@gmail.com

Сгоров Сергій Гаврилович. Старший викладач.

Факультет аеронавігації, електроніки та телекомунікацій, Національний авіаційний університет, Київ, Україна. Освіта: Харківський авіаційний інститут, (1979).

Напрям наукової діяльності: системи та процеси управління.

Кількість публікацій: 30.

E-mail: avionika2006@ukr.net

О. А. Сущенко, В. А. Голицин, А. А. Салюк, С. Г. Егоров. Автоматизированое проектирование автономных векторных измерителей

Рассмотрен процесс проектирования автономного векторного измерителя. Дана характеристика автономных векторных измерительных приборов, применяемых в беспилотной авиации. Пояснена концепция интеллектуального измерителя, относящаяся к исследуемому устройству. Приведена структура информационного обеспечения проектирования избыточного неортогонального измерительного прибора. Показана блок-схема процесса проектирования избыточных неортогональных конфигураций. Представлен процесс выбора оптимальной конфигурации автономных векторных измерительных приборов на основе избыточных неортогональных измерительных баз. Описаны автоматизированные процедуры выбора оптимальной конфигурации. Перечислены основные алгоритмы, необходимые для функционирования интеллектуальных векторных измерительных приборов. Приведен пример анализа неортогональных конфигураций. Полученные результаты применимы в измерительных системах беспилотной авиации. Также эти результаты могут быть полезны для других аэрокосмических приложений.

Ключевые слова: автономные векторные измерительные приборы; системы автоматизированного проектирования; неортогональная конфигурация; резервирование; интеллектуальный измерительный прибор.

Сущенко Ольга Андреевна. orcid.org/0000-0002-8837-1521. Доктор технических наук. Профессор.

Факультет аэронавигации, электроники и телекоммуникаций, Национальный авиационный университет, Киев, Украина.

Образование: Киевский политехнический институт, Киев, Украина, (1980).

Направление научной деятельности: системы стабилизации информационно-измерительных устройств, эксплуатируемых на подвижных объектах широкого класса.

Количество публикаций: 250.

E-mail: sushoa@ukr.net

Голицын Владимир Александрович. Аспирант.

Факультет аэронавигации, электроники и телекоммуникаций, Национальный авиационный университет, Киев, Украина.

Образование: Национальный авиационный университет, (2018).

Направление научной деятельности: информационно-измерительные приборы.

Количество публикаций: 5.

E-mail: vova.gol@ukr.net

Салюк Александр Алексеевич. Бакалавр.

Факультет аэронавигации, электроники и телекоммуникаций, Національний авіаційний університет, Київ, Україна.

Образование: Национальный авиационный университет, Киев, (2019).

Направление научной деятельности: информационно-измерительные приборы.

Количество публикаций: 1 .

E-mail:sashalok511@gmail.com

Егоров Сергей Гаврилович. Старший преподаватель.

Факультет аэронавигации, электроники и телекоммуникаций, Національний авіаційний університет, Київ, Україна.

Образование: Харьковский авиационный институт, (1979).

Направление научной деятельности: системы и процессы управления.

Количество публикаций: 30.

E-mail: avionika2006@ukr.net 